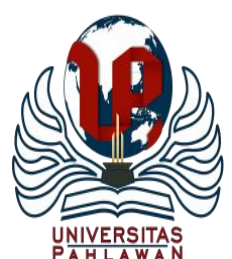

Jurnal Abdidas Volume 2 Nomor 6 Tahun 2021 Halaman 1345 - 1349

JURNAL ABDIDAS

http://abdidas.org/index.php/abdidas

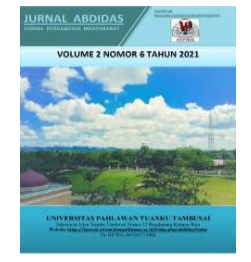

\title{
Pelatihan dan Pendampingan Penyusunan Proposal PKM-P Mahasiswa Program Studi Pendidikan Biologi
}

\author{
Abd. Hakim Laenggeng ${ }^{1}$, Samsurizal M. Suleman ${ }^{2}$, Moh. Sabran ${ }^{3}$ \\ Universitas Tadulako, Indonesia ${ }^{1,2,3,4}$ \\ E-mail : ah.laenggeng@yahoo.co.id ${ }^{1}$ biosamriz@gmail.com ${ }^{2}$ sabran_bios@ rocketmail.com ${ }^{3}$
}

\begin{abstract}
Abstrak
Kegiatan ini bertujuan untuk menambah pengetahuan, wawasan sekaligus meningkatkan kemampuan mahasiswa Program Studi Biologi dalam penyusunan proposal PKM-P (PKM-R). Hal ini dimaksudkan untuk meningkatkan sumberdaya manusia bagi mahasiswa dalam menghasilkan produk proposal yang berkualitas, memiliki daya saing yang kompetitif dalam mengikuti Program Kreativitas Mahasiswa, khususnya bidang PKM-P (PKM-R). Untuk mencapai tujuan tersebut, diterapkan metode dan pendekatan berupa pelatihan yang disesuaikan dengan target sasaran mitra. Kurangnya kemampuan dan pemahaman dalam merancang dan menyusun proposal terkait PKM mendorong tim pengabdian memadukan ide-ide dan gagasan dalam menyelesaikan permasalahan tersebut dengan melakukan kegiatan Pelatihan. Pelatihan menggunakan metode workshop berbasis kelompok. Materi yang diberikan terkait dengan Program Kreativitas Mahasiswa; identifikasi masalah, ide/gagasan dalam menetapkan topik dan teknik sitasi (mendeley) sampai pada sistematika dan teknik penyusunan proposal. Hasil pelatihan menunjukkan adanya peningkatan pengetahuan rata-rata peserta sebesar $21 \%$ dari sebelum kegiatan pelatihan secara umum mencapai rata-rata $69 \%$, setelah mengikuti kegiatan pelatihan, pengetahuan peserta meningkatkan menjadi rata-rata $90 \%$.
\end{abstract}

Kata kunci: pelatihan, mahasiswa, proposal PKM-P

\section{Abstract}

The purpose of community service activities is to improve knowledge, understanding, and skills in writing PKM (PKM-R) proposals as a student at the Department of Biology Education. Furthermore, this activity is to improve human resources in producing quality proposal and having competitive in Student Creativity Program (PKM), especially in the PKM-P (PKM-R). The methods and approaches used are training tailored to the students. Lack of ability and understanding in designing and compiling PKM proposals encourages servants to combine ideas in solving these problems by conducting training activities. The training uses a group-based workshop method. The material given is about the Student Creativity Program; identification of problems, ideas in setting topics and citation techniques (Mendeley) as well as systematics and techniques for preparing proposals. The results of the community service showed an increase in the average knowledge of participants by $21 \%$, before training in general knowledge was around $69 \%$, after participating in the training activities, students' knowledge increased to an average of $90 \%$.

Keywords: training, students, PKM-P proposals

Copyright (c) 2021 Abd Hakim Laenggeng, Samsurizal M. Suleman , Moh. Sabran

$\triangle$ Corresponding author

Address : Universitas Tadulako

Email : sabran_bios@rocketmail.com

DOI : https://doi.org/10.31004/abdidas.v2i6.480

ISSN 2721- 9224 (Media Cetak)

ISSN 2721- 9216 (Media Online) 
1346 Pelatihan dan Pendampingan Penyusunan Proposal PKM-P Mahasiswa Program Studi Pendidikan Biologi - Abd Hakim Laenggeng, Samsurizal M. Suleman, Moh. Sabran

DOI: https://doi.org/10.31004/abdidas.v2i6.480

\section{PENDAHULUAN}

Program Kreativitas Mahasiswa (PKM) yang diluncurkan oleh Direktorat Jenderal Pendidikan Tinggi pada tahun 2001 merupakan salah satu upaya untuk menumbuhkan, mewadahi, dan mewujudkan ide kreatif serta inovatif mahasiswa. Menurut Suryana (2011) dalam Hariani A. dan Margaretha Y, (2014), kreativitas merupakan kemampuan dalam mengembangkan gagasan dan solusi dalam memecahkan masalah sekaligus menemukan peluang baru.

Kreativitas merupakan penjelmaan integratif dari tiga faktor utama dalam diri manusia, yaitu: pikiran (kognitif), perasaan (afektif), dan keterampilan (psikomotorik). Dalam faktor pikiran terdapat imajinasi, persepsi dan nalar. Faktor perasaan terdiri dari emosi, estetika dan harmonisasi. Sedangkan faktor keterampilan mengandung bakat, faal tubuh dan pengalaman. Dengan demikian, agar mahasiswa dapat mencapai level kreatif, ketiga faktor termaksud diupayakan agar optimal dalam sebuah kegiatan yang diberi nama Program Kreativitas Mahasiswa (PKM).

Program Kreativitas Mahasiswa (PKM) dikembangkan untuk mengantarkan mahasiswa mencapai taraf pencerahan kreativitas dan inovasi berlandaskan penguasaan sains dan teknologi serta keimanan yang tinggi. Dalam rangka mempersiapkan diri menjadi pemimpin yang cendekiawan, wirausahawan mandiri dan arif, mahasiswa diberi peluang untuk mengimplementasikan kemampuan, keahlian, sikap, tanggungjawab, membangun kerjasama tim maupun mengembangkan kemandirian melalui kegiatan yang kreatif dalam bidang ilmu yang ditekuni (Kemdikbud, 2021).

Berbagai bentuk program kegiatan PKM yang dapat dilakukan oleh mahasiswa dalam rangka mengikuti kegiatan tersebut, antara lain melakukan penelitian dengan menyusun proposal untuk diusulkan dalam skema PKM-P (PKM-R). Untuk mendukung program tersebut, mahasiswa diharapkan mampu melaksanakan secara mandiri, namun mereka masih menemui berbagai kendala terutama ketidakmampuan mereka merancang sebuah penelitian yang akan dituangkan dalam bentuk proposal. Hal ini juga dialami oleh sebagian besar mahasiswa yang ada di Universitas Tadulako, tidak terkecuali mahasiswa pada program Studi Pendidikan Biologi FKIP UNTAD. Permasalahan lain yang ditemukan adalah kurangnya minat serta ketidakmampuan mahasiswa menemukan dan mengemukakan ide atau gagasan yang layak untuk dijadikan topik penelitian.

Hasil penelusuran terhadap beberapa mahasiswa pada program studi Pendidikan Biologi Jurusan Pendidikan MIPA FKIP Universitas Tadulako melalui diskusi dan wawancara, teridentifikasi beberapa permasalahan yaitu :

1. Kurangnya minat dan kemampuan mahasiswa dalam menemukan, ide atau gagasan yang layak untuk diangkat dalam Program Kreativitas Mahasiswa.

2. Umumnya mahasiswa masih kurang memahami teknik dan cara penyusunan proposal, terutama yang berkaitan dengan Program Kreativitas Mahasiswa. 
1347 Pelatihan dan Pendampingan Penyusunan Proposal PKM-P Mahasiswa Program Studi Pendidikan Biologi - Abd Hakim Laenggeng, Samsurizal M. Suleman, Moh. Sabran

DOI: https://doi.org/10.31004/abdidas.v2i6.480

3. Masih kurangnya kegiatan-kegiatan pelatihan yang dapat diikuti oleh para mahasiswa terutama yang berkaitan dengan Program Kreativitas Mahasiswa (PKM), sehingga kemampuan dan pemahaman merekapun menjadi terbatas .

Berdasarkan pada permasalahan tersebut di atas, mendorong pengabdi untuk mengatasi beberapa permasalahan yang telah dikemukakan melalui kegiatan pelatihan dan pendampingan penyusunan Proposal PKM-P bagi Mahasiswa Program Studi Pendidikan Biologi.

Kegiatan ini bertujuan untuk menambah pengetahuan, wawasan sekaligus meningkatkan kemampuan mahasiswa Program Studi Biologi dalam penyusunan proposal PKM-P. Hal ini dimaksudkan untuk meningkatkan sumberdaya manusia bagi mahasiswa dalam menghasilkan produk proposal yang berkualitas, memiliki daya saing yang kompetitif dalam mengikuti Program Kreativitas Mahasiswa, khususnya bidang PKM-P (PKM-R).

\section{METODE}

Kegiatan pelatihan dan pendampingan penyusunan proposal Program Kreativitas Mahasiswa skema Penelitian/Riset menggunakan metode workshop berbasis kelompok. Pelaksanaan kegiatan dilakukan secara luring dan daring. Secara umum pelaksanaan kegiatan pengabdian ini dilakukan dalam beberapa tahapan berikut.

Tahap pertama adalah melakukan penjajakan pengetahuan dan kemampuan Mahasiswa terkait Program Kreativitas Mahasiswa melalui pemberian pre test. Tahap kedua, penyajian materi tentang 1) Program Kreativitas Mahasiswa; 2) Ide Gagasan Topik dalam PKMPenelitian/Riset dan Teknik Sitasi (Mendeley); dan 3) Sistematika dan Teknik Penulisan Proposal. Tahap ketiga adalah Unjuk Kerja melalui penyusunan draf proposal secara berkelompok dengan pendampingan langsung oleh tim. Tahap keempat, presentasi draf proposal setiap kelompok dan diakhir kegiatan pemberian post test.

\section{HASIL DAN PEMBAHASAN}

Tahapan pelaksanaan kegiatan telah dimulai sejak bulan Mei 2021 dengan melakukan identifikasi dan pemetaan permasalahan melalui wawancara dan diskusi dengan beberapa mahasiswa terkait program kreativitas mahasiswa. Kendala utama yang dihadapi selama proses kegiatan mulai dari persiapan sampai pada tahap pelaksanaan kegiatan adalah situasi dan kondisi pandemi Covid-19 yang berdampak pada pembatasan aktifitas atau kegiatan. Kendala ini dapat diantisipasi dengan melakukan kegiatan pelatihan secara luring pada tanggal 16-17 Juli 2021 dengan menerapkan dan mengikuti standar prokol kesehatan Covid-19 yang ketat.

Pelaksanaan kegiatan pelatihan dilakukan dengan beberapa tahapan, pada hari pertama dimulai dengan memberikan pre test kepada peserta. Hasil pre test peserta diperoleh skor ratarata $69 \%$. Kemudian dilanjutkan dengan penyajian materi oleh narasumber. Materi pertama disampaikan oleh Bapak Moh. Sabran selaku anggota tim pengabdi dengan topik bahasan Program Kreativitas dan Inovasi Mahasiswa; materi kedua dengan judul "Ide/Gagasan Topik 
1348 Pelatihan dan Pendampingan Penyusunan Proposal PKM-P Mahasiswa Program Studi Pendidikan Biologi - Abd Hakim Laenggeng, Samsurizal M. Suleman, Moh. Sabran

DOI: https://doi.org/10.31004/abdidas.v2i6.480

dalam PKM dan Teknik Sitasi (Mendeley) dibawakan oleh Bapak Manaf Trianto. Beliau merupakan salah satu staf pengajar sekaligus merupakan alumni pada Program Studi Pendidikan Biologi FKIP Universitas Tadulako yang mememiliki prestasi pada bidang PKM semasa menjadi mahasiswa dan materi ketiga tentang "Sistematika dan Teknik Penulisan Proposal" dibawakan oleh Bapak Samsurizal M. Suleman selaku anggota tim pengabdi. Adapun Bapak Abd. Hakim Laenggeng selaku ketua tim memberikan penguatan, motivasi kepada para peserta bagaimana menjadi mahasiswa berprestasi dan mampu berdaya saing baik secara nasional maupun internasional.

Pada hari kedua pelaksanaan kegiatan pelatihan Penyusunan Proposal PKM-P para peserta mulai menyusun kerangka draf proposal secara berkelompok. Penuntasan proposal kemudian dilanjutkan oleh masing-masing kelompok dihari-hari berikutnya. Selama proses penyusunan para peserta tetap dipandu, diberikan arahan dan dibimbing langsung oleh tim pengabdi baik secara daring maupun luring. Diakhir kegiatan peserta kemudian diberikan post test untuk melihat seberapa besar pemahaman dan pengetahuan peserta terkait program kreativitas mahasiswa.

Dari hasil post test yang diberikan diperoleh nilai skor rata-rata 90\%, hal ini menunjukkan ada peningkatan pengetahuan para peserta sebesar $21 \%$ dari sebelum mengikuti kegiatan pelatihan. Peningkatan pengetahuan para peserta tidak lepas dari keseriusan dan antusias pada saat mengikuti kegiatan, hal ini terlihat dari peran aktif para peserta dalam bertanya dan diskusi. Peningkatan pengetahuan peserta setelah mengikuti kegiatan dapat terjadi karena keseriusan para peserta dalam mengikuti materi sehingga apa yang disampaikan dapat diterima dengan baik (Suleman M.S., dkk, 2018). Disamping itu motivasi yang tinggi untuk terus belajar menjadi salah satu pendorong yang bisa meberikan kontribusi terhadap peningkatan kemampuan mereka. Grabek (2006) dalam Musfah, J (2011), mengatakan "Tanpa motivasi kita berhenti berbuat dan melakukan sesuatu yang benar-benar kita ingin raih".

Kegiatan pelatihan semacam ini telah memberikan inspirasi dan dorongan kepada peserta untuk terus belajar, berinovasi dan berkreasi dalam rangka menambah wawasan dan pengetahuan mereka. Para peserta menilai kegiatan pelatihan yang mereka ikuti memberikan kontribusi terhadap pengetahuan dan pengembangan diri mereka, sehingga nantinya bisa berkontribusi dan ikut serta dalam kegiatan program kreatifitas mahasiswa yang dilunjurkan oleh Direktorat Kemahasiswaan Dirjen Pembelajaran dan Kemahasiswaan Kementerian Pendidikan, Kebudayaan, Riset dan Teknologi yang memiliki berbagai bidang kompetisi yang dapat diiukuti oleh para mahasiswa.

Berkenaan dengan hal tersebut, tim pengabdi berkomitmen untuk terus memberikan dorongan dan memotivasi kepada peserta meskipun kegiatan telah berakhir. Bimbingan dan pendampingan akan terus dilakukan kepada peserta dalam rangka menyiapkan draf proposal yang nantinya dapat diajukan untuk dikompetisikan pada program kreativitas mahasiswa, termasuk dalam hal menjadi dosen 
1349 Pelatihan dan Pendampingan Penyusunan Proposal PKM-P Mahasiswa Program Studi Pendidikan Biologi - Abd Hakim Laenggeng, Samsurizal M. Suleman, Moh. Sabran

DOI: https://doi.org/10.31004/abdidas.v2i6.480

pendamping atau pembimbing pada program kreativitas mahasiswa yang akan datang.

\section{SIMPULAN}

Berdasarkan hasil evaluasi capaian pelaksanaan kegiatan pelatihan dan pendampingan penyusunan Proposal PKM-P Mahasiswa Program Studi Pendidikan Biologi disimpulkan beberapa hal sebagai berikut:

a) Tingkat pengetahuan peserta sebelum dan sesudah kegiatan pelatihan meningkat sebesar $21 \%$, dimana skor rata-rata sebelum kegiatan diperoleh sebesar 69\%. Setelah mengikuti keseluruhan rangkaian kegiatan pelatihan, tingkat pengetahuan peserta diperoleh skor rata-rata sebesar $90 \%$.

b) Antusias dan motivasi peserta cukup tinggi dalam mengikuti kegiatan pelatihan, serta memiliki kemauan yang besar untuk terus belajar, karena kegiatan semacam ini mereka nilai memberi manfaat bagi pengembangan diri mahasiswa.

c) Pendampingan terhadap peserta masih perlu terus dilakukan, untuk memberikan dorongan dan motivasi dalam hal mengikuti kegiatan program kreatifitas mahasiswa.

\section{UCAPAN TERIMA KASIH}

Ucapan terima kasih kami sampaikan kepada pimpinan Universitas Tadulako, Lembaga Penelitian dan Pengabdian Masyarakat serta Dekan FKIP Universitas Tadulako yang telah mengalokasikan dana BLU melalui DIPA Fakultas tahun anggaran 2021, sehingga pengabdian ini dapat dilaksanakan.

\section{DAFTAR PUSTAKA}

Hariani A. dan Margaretha Y. 2014. Pengembangan Kreativitas Mahasiswa dengan Menggunakan Brainstorming dalam Mata Kuliah Kewirausahaan. Jurnal Manajemen, Vol. 13, No. 2, Mei 2014. Hal 175-192.

Kemdikbud. 2021. Pedoman Umum Program Kreativitas Mahasiswa. Direktorat Kemahasiswaan Dirjen Pembelajaran dan Kemahasiswaan Kemendikbud. Jakarta.

Musfah J. 2011. Peningkatan Kompetensi Guru Melalui Pelatihan dan Sumber Belajar. Kencana (Divisi dari Prenamedia Group). Jakarta.

Suleman M.S. dkk. 2018. Peningkatan Keterampilan Asisten Laboratorium Biologi dalam Praktikum Biologi Perairan. Pengabdian Kepada Masyarakat, Hibah FKIP UNTAD. Palu. 